AGRICULTURE AND BIOLOGY JOURNAL OF NORTH AMERICA

ISSN Print: 2151-7517, ISSN Online: 2151-7525, doi:10.5251/abjna.2010.1.5.1050.1056

(C) 2010, ScienceHu $\beta$, http://www.scihub.org/ABJNA

\title{
Differences between some plants in selenium accumulation from supplementation soils with selenium
}

\author{
H. Kh. Ahmed \\ Soils and Water Dept., Faculty of Agric., Al-Azhar Univ, Egypt \\ ABSTRACT
}

During 2008-2009, a pot experiment was conducted using ;Loamy sandy soil as growth medium for lettuce (Actuca sativa var . Grtelit), tomato (Lycopersican esculentum var . Hagein Master 100 ), radish (Raphanus sativus var .Indiaradish) and strawberry (Tioga) to study the differences between some plants in selenium accumulation from supplementation soils with selenium .The plants for each crop examined were divided into five treatment groups, each with four replicates : (1) without selenium addition (2) each plant received a total of $2.0 \mathrm{mg}$ of an inorganic selenium per $\mathrm{kg}$ of soil. (3) each plant received a total of $2.0 \mathrm{mg}$ of an organic of selenium per $\mathrm{kg}$ of soil (4) each plant received a total of $30 \mathrm{mg}$ of an inorganic of selenium per $\mathrm{kg}$ of soil , and (5) each plant received a total of $30 \mathrm{mg}$ of an organic of selenium per $\mathrm{kg}$ of soil . Also, in the laboratory studied of the effect of selenium on seed Bioassays .Concentrations of 0,10,25,50,100 and 200ppm were used in the bioassays. The obtained results revealed that increasing selenium levels decreased the fresh weights for the four plants tested Statistically significant differences in appetence, plant production, and fresh weights of the plant produced were studied. Next, the amount of selenium retained in the edible plants, no edible plant, and soil for each was analyzed by acid digestion followed by hybride generation atomic absorption analysis. Finally, inhibition effects on the seeds of the addition with an inorganic form of a maximum of $95 \%$ retained in the edible portion of lettuce plants.

Keywords: Soil, supplementation, selenium

\section{INTRODUCTION}

Selenium occurs in the soil in its elemental form. Sedimendary and many shale rock materials were the parent materials for the soil of most of our cultivated crops. These soils generally have low $\mathrm{Se}$ content, and the grains and vegetables grown on these soils generally have low Se concentration. Selenium is biologically important because it's essential in plant metabolism .Selenium was discovered in 1818 by the chemist J.J.Berzelius in Gripsholm, Sweden. He named this new element selenium after "selene" the Greek goddess of the moon. Selenium has long been recognized for its toxic effect on farm plants and animals. Macro polo, in 1295, may have been describing chronic selenium poisoning when in his account of his travels in Westren China, he wrote that a poisonous plant growing there, if eaten by their beasts of burden , caused the hooves of the animals to drop off. In the rarely 1930s, the research demonstrated that selenium in the forage in certain areas was responsible for selenium poisoning In the late 1950s, selenium was shown to be an essential nutrient (Mayland et al ., 1989) .For many years, selenium has been recognized as an essential trace element necessary for both human and livestock nutrition Frankenberger et at(1998). With regard to human nutrition, there have been numerous attempts to associate low or suboptimal levels of selenium intake with a wide variety of human diseases,such as heart disease , cystic fibriosis, and cancer DC(1983) Selenium has been recognized to play an important role in several selenoproteins Burk et at(1993). The recent interest in selenium has resulted from the promise it has shown in the treatment of lung , prostate , and colon types of cancer Clark et at(1996) .The National Research Council has established a Recommended Dietary Allowance of selenium for humans, 55 and $70 \mu \mathrm{g} /$ day for men and women , respectively DC (1989). It has been shown that the most effective way to increase the amount of selenium in cultivated crops is to add selenite or selenate to fertilizers, spray to crops with selenium salts, or treat the seeds with aqueous selenium Bisberg et al (1969);Gissel-Nielsen et al (1970;1977) ; Ylaranta (1985).

Nutitional supplements have also been recommended to increase daily selenium; however, recent studies have shown that the amount of selenium in over-the- counter supplements can be 
much lower than adveristed Carvalho et al .,2000). El-Raies (2001) found that the average of Se concentration in berssem plant grown on Giza governorate was $0.083 \mathrm{mg} / \mathrm{kg}$ dry weight. The results showed that the mean values of total and available selenium in the soil as well as plant content of Se were low $(0.28,0.045$ and $0.027 \mathrm{mg} / \mathrm{kg}$ respectively while the mean values of total available phosphorus and plant content of phosphorus were high Ghanam et al.,2003.Also El-Raies et al .,2004 reported that Se losses by incubation ranged from $0 \mathrm{Cw}$ to $28.05 \%$ (PN) with an average of $11.91 \%$. The $\mathrm{N}_{2}$ a Se activity of bean plants was increased with increasing the levels of Se and humic acid addition EL-Ghanam and ELGhozoli (2006) .

Attempts have also been made to increase the amount of selenium available in the soil for animal foder and human food. A range of $0.05-0.1 \mathrm{mg} / \mathrm{kg}$ dry matter is typically used; however, after chronic exposure to fodder that exceeds $1 \mathrm{mg} / \mathrm{kg}$ dry matter toxic effects can be expectedGisset-Nielsen-G(1998). Vegetables rich in selenium have been shown to contribute as much as $28-32 \%$ of the daily intake in Northern MexicoWyatt, et al(1996). The objective of this study was to evaluate the feasibility of selenium supplementation for some agricultural crops. This includes the form of selenium -both organic and inorganic forms to supply, as well as the type of crop in a controlled environment. After the agricultural crops were analyzed and selenium was found to remain in the soil, the effects of selenium supplementation on germination and plant growth were studied. Selenium has not been demonstrated as an essential nutrient for plant growth; therefore, the effect of selenium concentration was also studied

\section{MATERIALS AND METHODS}

A laboratory experiment was carried out to assess the uptake of the adopted plants of selenium from selenium on seed Bioassays. Therefore, seeds from lettuce (catuca sativa var. Grtelit), tomatoes (lycopersicon esculentum var. Hagrin Master 100), and radish (Raphanus sativu var. Indiaradish) were evaluated for inhibition effects from selenium supplementation. Seeds were washed with soap and water, and then rinsed with distilled water, and gravity filtered using Whatman No.1 filter paper. Seeds were evaluated using a randomized design with each concentration in triplicate. Concentrations of $0,10,25,50,100$, and 200ppm were used in the bioassays. Using trays with individual wells, 15 seeds counted and distributed to each well, which was lined with Whatman No.1 filter paper. The trays were then covered with plastic wrap and a glass plate and placed under a 40-w fluorescent light with a photoperiod of $12 \mathrm{~h}$ light/12h dark for 10days.Inhibition parameters compared included fresh weight, dry weight, and percent germination of the seeds.

A pot experiment was conducted at growth chamber with a photoperiod of $12 \mathrm{~h}$ light $/ 12 \mathrm{~h}$ dark a relative humidity of $70 \%$, a constant temperature of $25^{\circ} \mathrm{C}$ .Thirty $\mathrm{cm}$ diameter earthon pots were cleaned and seven kilograms of $2 \mathrm{~mm}$-sieved soil were put in each experimental pot. The plants \{tomato, lettuce, radish and strawberry (Tioga)\} were grown in loamy sand soil pots and subjected to the following selenium supplementation conditions. The plants for each crop examined were divided into five treatment groups, each with trireplicates(1) without selenium addition (control). (2) each plant received a total of $2.0 \mathrm{mg}$ of an inorganic form (sodium selenate) of selenium per $\mathrm{kg}$ of soil.(3)each plant received a total of $2.0 \mathrm{mgof}$ an organic form (organic Se ) of selenium per $\mathrm{kg}$ of soil .(4) each plant received a total of $30 \mathrm{mg}$ of an inorganic form of selenium per $\mathrm{kg}$ of soil; and (5) each plant received a total of $30 \mathrm{mg}$ of an organic form of selenium per $\mathrm{kg}$ of soil. Tests 2 and 3 were considered to have received an "optimum" level of selenium and tests 4 and 5 to receive a "supraoptimal" amount of selenium. We chose the supplementation concentration of $2 \mathrm{mg}$ of Se/kg of soil on the basis of previous studies (Cary et al (1973, Eurola et al (1989), and $30 \mathrm{mg}$ of Se $/ \mathrm{kg}$ of soil was used as a much higher amount to test toxicity effects .

Soil mechincal analysis was achieved on samples prior to soil texture was defined according to Piper (1950). Regarding soil chemical analysis, soil pH and EC and soluble cations and anions were achieved according to Jackson (1973), organic matter and CEC to Page et al (1982). The obtained physical and chemical analysis of the studied soil are depicted in Table (1).

Table 1. Soil physical and chemical properties .

\begin{tabular}{|c|c|}
\hline Soil physical properties & Soil chemical pro \\
\hline \multirow{4}{*}{$\begin{array}{lc}\text { Coarse sand\% } & 10.60 \\
\text { Fine sand\% } & 65.82 \\
\text { Silt } & 10.65 \\
\text { Clay } & 12.93 \\
\text { Texture class loamy sand }\end{array}$} & Cation meg/L Anion meg/L \\
\hline & \\
\hline & $\mathrm{Ca} \mathrm{Mg} \mathrm{K} \mathrm{NaCO} \mathrm{CO}_{3} \mathrm{H}$ \\
\hline & $\begin{array}{lllllll}1.68 & 0.88 & 0.5 & 1.4 & 0.0 & 0.911 .08 & 2.47\end{array}$ \\
\hline & $\begin{array}{lll}\mathrm{pH} 8.4 & 0 . \mathrm{M} & 0.15 \\
\mathrm{CaCo}_{3} \% & 0.43 \\
\mathrm{EC} \mathrm{dsm}^{-1} \quad 4.50 & \end{array}$ \\
\hline
\end{tabular}

The amount of Se in the fruit and vegetables,,(leaves, stem, and roots) was analyzed by hydride generation 
atomic absorption to determine if any any acumulation of Se was present and if the plant absorbed the Se but retained it in the green portions of plants rather than the fruit and vegetables. The amount of Se retained in the soil was determined by hydride generation atomic absorption.

The plant and soil samples were digested in the following manner, keeping in mind the volatile nature of Se Inhat,M(1992). The soil samples were digested in the following manner. Statistical analysis was performed as for two factorial randomized complete blook design (Gomez and Gomez 1984). The means were separated by the least siginficant difference.

\section{RESULTS AND DISCUSSION}

After addition of the fruit and vegetables of interest was completed, several effects from the supplementation were examined, including differences in apperence, amount of Se retained and surrounding environmental changes.

Fig. 1. Effect of selenium on lettuce seed germination.

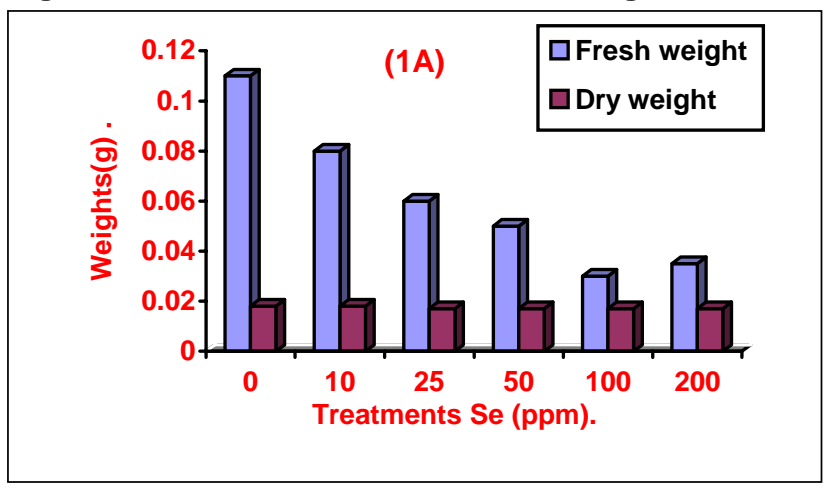

Fig. 2 Effect of selenium on tomato seed germination.

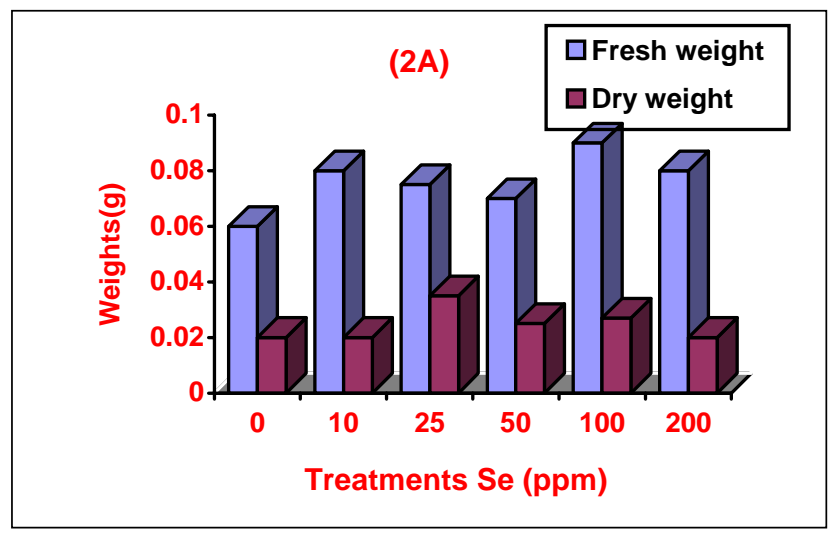

For the lettuce seeds, figure (1) show that the fresh weights decreased with increasing Se concentration. However, the dry weights remained constant over the range of Se concentration. The percent germination showed a statistically significant decrease with an increase in Se concentration.An $\mathrm{Ec}_{50}$ was determined by interpolation to be $36 \mathrm{ppm}$, at which $50 \%$ of the seeds showed inhibition of germination.

For the tomato seeds, figure (2) shows that the fresh weights and dry weights remained constant over the range of Se concentration. The percent germination showed a statistically significant relationship: an increase in Se concentration caused a decrease in percent germination.An $\mathrm{Ec}_{50}$ was determined by interpolation to be $29 \mathrm{ppm}$, at which $50 \%$ of the seeds showed inhibition of germination. Although the percent germination decreased at a lower concentration than for the lettuce seeds, of yhose seeds which did germinate, the growth was not severely inhibited until a Se concentration of 100ppm
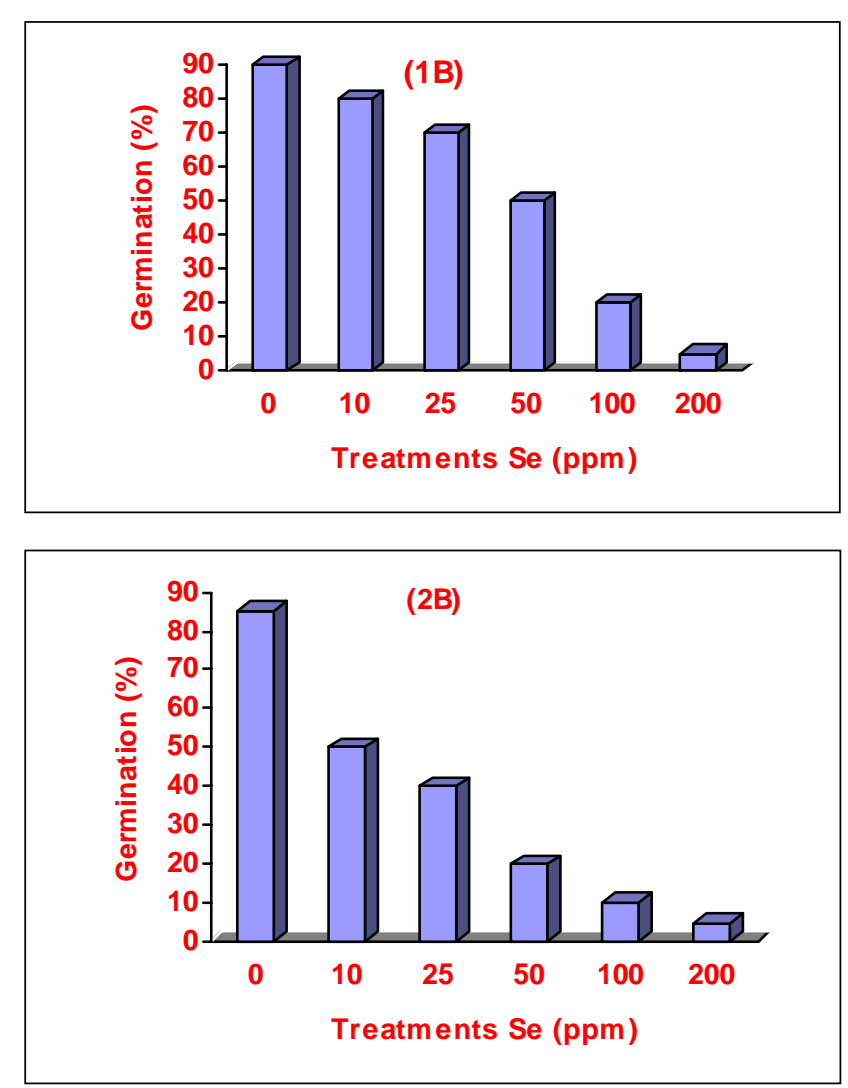
Fig 3. Effect of selenium on radish seed germination.

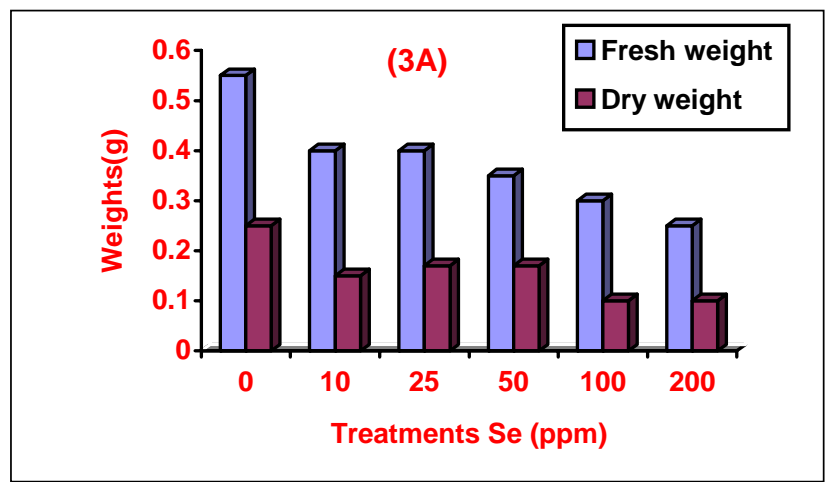

For the radish seeds, figure(3)shows that the fresh weights showed decrease with increasing Se concentration; however, the dry weights remained constant. The percent germination showed a statistically significant decrease with an increase in Se concentration. The EC50 was interpolation to give a concentration of $38 \mathrm{ppm}$, at which $50 \%$ of the seeds showed inhibition of germination. The percent germination was similar to the result from the lettuce seed study.

The results from these seed bioassays indicate that several important factors need to consider for agricultural Se addition. First, although Se is not an essential nutrient for plants, at high enough concentrations, the growth and germination of seeds can be inhibited. Thishas been previously demonstrated with selenate $\left(\mathrm{SeO}_{4}{ }^{-2}, \mathrm{HSeO}_{3}\right)$ and selenite $\left(\mathrm{SeO}_{3}{ }^{2-}, \mathrm{HSeO}_{3}\right)$ (Carlson et al 1989). Finally, the most important conclusion which can be drawn from the seed bioassays is that, in all the agricultural crops studies, a concentration higher than 29ppm, for the most sensitive seeds studied is required to inhibit germination of the seeds. This is very important,

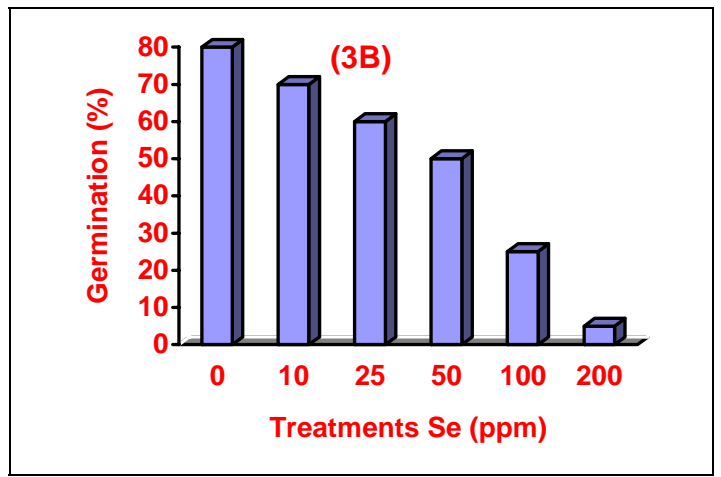

because the highest concentration of Se let in the soil from our agricultural crop studies was 1.9ppm (high organic Se treatment of tomatoes). The amount of Se left in the soil after the first round a supplementation would not be a high enough concentration to inhibit the germination of the seeds of any of the agricultural crops that were studied. Therefore, the concentration of Se left in the soil would not be toxic when new seeds were planted, and several crops could be grown and supplemented in the same soil.

The edible portions of the Se added fruit and vegetable agricultural crops examined were individually weighed and compared with the controls (Table2). For both the tomato and strawberry plants, no statistically significant differences were observed when the fresh weights of the fruits were examined, However statistically significant differences were observed for fresh weights of the edible portions of the radish plants, comparing the control with the low inorganic treatment, and of the lettuce plants, comparing the control with the high organic treatment.

Table 2. Effect of Se addition on fresh weights(g) of plants.

\begin{tabular}{|l|c|c|c|c|}
\hline \multirow{2}{*}{ Treatments } & \multicolumn{4}{c|}{ Plants } \\
\cline { 2 - 5 } & Tomato & Strawberry & Radish & Lettuce \\
\hline Control & 33.50 & 6.30 & 4.80 & 0.63 \\
Low inorganic & 32.10 & 8.50 & 9.70 & 1.15 \\
High inorganic & 27.50 & 7.60 & 9.20 & 0.86 \\
Low organic & 11.50 & 5.50 & 6.30 & 1.20 \\
High organic & 0.00 & 4.51 & 10.6 & 0.91 \\
\hline
\end{tabular}

The amount of Se retained in the plants and soil was quantified using atomic absorption (Table3). The amount of Se in the edible portion of the plant was first determined for each plant studied. For all plants studied, the amount of Se absorbed and retained in the edible portions was statistically significantly higher in the inorganic treatments when compared with organic treatments. This was appositive result, 
because the addition of inorganic Se would not only be more economical, but would also result in better retention of Se than the addition of organic Se. Next, the amount of Se retained by the inedible parts of the plants (i.e., leaves, stems and roots) was collectively quantified, again using hydride generation atomic absorption. For all of the plants studied, the amount of $\mathrm{Se}$ absorbed and retained in the inedible portions was statistically significantly higher in the inorganic treatments than in the soil for each pant was then quantified using hydride generation atomic absorption. For the tomato and lettuce crops, there were no statistically significant differences observed for any of the treatments, another positive result favoring inorganic Se addition. Although some Se remains in the soil after treatment, using inorganic or organic Se sources did not make a statistically significant difference, and inorganic Se sources were less expensive than organic sources. For the strawberry and radish plants, the amounts of Se remaining in the soil after the high inorganic treatments were statistically significantly lower than the amounts of Se remaining in the soil after the high organic treatments. Again, this is another positive result favoring inorganic Se addition some Se remains in the soil after treatment, using inorganic Se would leave less Se to accumulate in the soil.

Although, Se has not been demonstrated to be an essential element for plants, the plants tested can assimilate it and respond in one of two ways: as a Se source for humans or as a Se scavenger for Secontaminated soils, depending upon whether the edible or non edible portions are to be used. Our results show that Se addition of these selected plants is feasible, with a wide range (between 0.1 and > $98.5 \%$ ) of $\mathrm{Se}$ retained in the edible portion .The lettuce plants seemed to retain the most Se $(2-3 \%)$ in the edible portion of the plant compared to the other plants studied(Table3).

Table 3. Comparison of the amount of Se retained after addition with selenium( $\mathrm{mg} / \mathrm{g})$

\begin{tabular}{|c|c|c|c|c|c|c|c|c|c|c|c|}
\hline \multirow[b]{2}{*}{ Treatments } & \multicolumn{2}{|c|}{ Tomato } & \multirow[b]{2}{*}{ Soil } & \multicolumn{2}{|c|}{ Strawberry } & \multirow[b]{2}{*}{ Soil } & \multicolumn{2}{|c|}{ Radish } & \multirow[b]{2}{*}{ Soil } & \multirow{2}{*}{$\begin{array}{l}\text { Lettuce } \\
\text { edible }\end{array}$} & \multirow[b]{2}{*}{ Soil } \\
\hline & edible & $\begin{array}{c}\text { non } \\
\text { edible }\end{array}$ & & edible & $\begin{array}{c}\text { non } \\
\text { edible }\end{array}$ & & edible & $\begin{array}{c}\text { non } \\
\text { edible }\end{array}$ & & & \\
\hline Control & 0.12 & 10.10 & 0.23 & 0.06 & 9.23 & 0.27 & 0.03 & 2.48 & 0.35 & 0.90 & 0.07 \\
\hline Low inorganic & 0.40 & 130.1 & 1.03 & 0.13 & 120.51 & 0.60 & 0.16 & 7.65 & 0.70 & 1.32 & 0.04 \\
\hline Hiah inorganic & 0.25 & 118.2 & 1.75 & 0.20 & 105.45 & 1.55 & 0.27 & 20.56 & 1.95 & 3.61 & 0.09 \\
\hline Low organic & 0.30 & 126.2 & 0.90 & 0.11 & 122.61 & 1.11 & 0.14 & 6.50 & 1.25 & 1.41 & 0.19 \\
\hline High organic & 0.00 & 120.5 & 2.20 & 0.17 & 109.10 & 2.35 & 0.41 & 16.40 & 2.65 & 2.91 & 0.09 \\
\hline
\end{tabular}

Some plants (tomato and strawberry) managed to remove all of the added $\mathrm{Se}$ in non edible portions, which indicates that these plants could be used as Se scavengers in contaminated soils. The conditions for the scavenging procedure deserve consideration Using an inorganic Se source, such as Selenium dioxide, proved to be better for inorganic Se content than using an inorganic Se source, such as selenium ethionine, for the following reasons. First, the edible portions of the plants examined retained statistically significant greater amounts of the inorganic Se source used than the organic Se source. Second, the inorganic Se source was more cost-effective when compared with the organic Se source. Finally, the amount of Se left in the soil when the inorganic Se source was used was less than that when the organic source was used. All of these factors proved that using inorganic Se as a source for Se addition would be ideal, but the use of tomatoes as a Se scavenger could be even more promising

Supplementing a Se-deficient diet can be more aged in several ways. Rayman (2002) suggests enhancements with Brazil nuts, but their fat content may limit the usefulness of the delicious nuts. Fish, crabs, and other shellfish are moderately good sources of Se, but improvements in the concentration of $\mathrm{Se}$ in the blood and tissues are variable, Rayman (2002). On the other hand, the plants studied here have an attractive feature: they are nutritious, and tomatoes and lettuce, commonly used with many fast foods, could cater to contemporary tastes while providing a Se supplement benefit. One of the problems, however, is the effect of soil Se on seeds and this issue was addressed.

Soil samples from the tomato, strawberry, radish and lettuce plants were examined using hydride generation atomic absorption to weight percentages of significant elements (Tables4-7). For the lettuce, tomato, and radish samples was less than the initial amount of sulfur in the control. Also, with the high treatments, all of these plants were shown to absorb more Se than the optimum treatment plants, and the amount of sulfur remaining in the soil for the optimum treatment plants was less than the amount of sulfur 
remaining in the soil for the high treatment plants . This suggests that the $\mathrm{Se}$ is substituting for the sulfur in these plants, which has been previously demonstrated by Anderson(1983).

Table 4. Effect of selenium addition on available elements in lettuce soil samples(\%).

\begin{tabular}{|l|c|c|c|c|c|c|c|c|c|}
\hline \multirow{2}{*}{ Treatments } & \multicolumn{9}{c|}{ Available elements } \\
\cline { 2 - 9 } & $\mathbf{N a}$ & $\mathbf{M g}$ & $\mathbf{C a}$ & $\mathbf{P}$ & $\mathbf{S}$ & $\mathbf{A l}$ & $\mathbf{F e}$ & $\mathbf{C u}$ & $\mathbf{T i}$ \\
\hline Control & 0.23 & 0.35 & 2.30 & 1.00 & 1.90 & 2.05 & 2.60 & 0.90 & 0.15 \\
Low inorganic & 0.00 & 0.00 & 2.90 & 0.75 & 0.60 & 2.65 & 3.10 & 0.76 & 0.50 \\
High inorganic & 0.00 & 0.00 & 4.11 & 2.20 & 1.50 & 2.45 & 2.61 & 0.00 & 0.20 \\
Low organic & 0.00 & 0.00 & 1.15 & 0.75 & 0.66 & 15.50 & 1.85 & 1.82 & 0.00 \\
High organic & 0.00 & 0.00 & 1.51 & 0.73 & 1.51 & 1.80 & 3.20 & 0.00 & 0.00 \\
& & & & & & & & & \\
\hline
\end{tabular}

Table(5): Effect of selenium addition on available elements in tomato soil samples(\%).

\begin{tabular}{|l|c|c|c|c|c|c|c|c|c|}
\hline \multirow{2}{*}{ Treatments } & \multicolumn{9}{c|}{ Available elements } \\
\cline { 2 - 9 } & $\mathbf{N a}$ & $\mathbf{M g}$ & $\mathbf{C a}$ & $\mathbf{P}$ & $\mathbf{S}$ & $\mathbf{A l}$ & $\mathbf{F e}$ & $\mathbf{C u}$ & $\mathbf{T i}$ \\
\hline Control & 1.51 & 1.91 & 18.55 & 1.88 & 15.30 & 8.22 & 4.77 & 2.00 & 0.00 \\
Low inorganic & 1.85 & 2.55 & 20.70 & 1.80 & 10.50 & 10.66 & 5.22 & 2.20 & 0.00 \\
High inorganic & 1.40 & 1.82 & 25.80 & 3.11 & 12.30 & 9.67 & 6.10 & 0.00 & 0.00 \\
Low organic & 1.00 & 1.35 & 14.01 & 3.60 & 6.44 & 5.11 & 3.90 & 2.90 & 0.00 \\
High organic & 0.00 & 1.71 & 11.66 & 1.65 & 9.25 & 4.35 & 6.20 & 1.14 & 0.00 \\
\hline
\end{tabular}

Table 6. Effect of selenium addition on available elements in strawberry soil samples(\%).

\begin{tabular}{|l|c|c|c|c|c|c|c|c|c|}
\hline \multirow{2}{*}{ Treatments } & \multicolumn{9}{c|}{ Available elements } \\
\cline { 2 - 9 } & $\mathbf{N a}$ & $\mathbf{M g}$ & $\mathbf{C a}$ & $\mathbf{P}$ & $\mathbf{S}$ & $\mathbf{A l}$ & $\mathbf{F e}$ & $\mathbf{C u}$ & $\mathbf{T i}$ \\
\hline Control & 0.06 & 1.81 & 15.60 & 10.95 & 12.60 & 9.50 & 3.95 & 2.85 & 1.88 \\
Low inorganic & 0.00 & 0.00 & 11.81 & 6.17 & 4.55 & 8.11 & 5.60 & 3.22 & 2.15 \\
High inorganic & 1.52 & 1.93 & 14.46 & 12.15 & 4.85 & 9.75 & 9.40 & 5.25 & 1.36 \\
Low organic & 0.00 & 1.62 & 15.73 & 13.30 & 3.50 & 8.75 & 12.50 & 2.65 & 1.95 \\
High organic & 2.00 & 2.16 & 16.95 & 10.10 & 6.63 & 11.20 & 4.35 & 3.75 & 0.90 \\
& & & & & & & & & \\
\hline
\end{tabular}

Table 7 Effect of selenium addition on available elements in radish soil samples(\%).

\begin{tabular}{|l|c|c|c|c|c|c|c|c|c|}
\hline \multirow{2}{*}{ Treatments } & \multicolumn{9}{c|}{ Available elements } \\
\cline { 2 - 9 } & $\mathbf{N a}$ & $\mathbf{M g}$ & $\mathbf{C a}$ & $\mathbf{P}$ & $\mathbf{S}$ & $\mathbf{A l}$ & $\mathbf{F e}$ & $\mathbf{C u}$ & $\mathbf{T i}$ \\
\hline Control & 1.48 & 2.01 & 17.84 & 1.22 & 15.00 & 7.35 & 4.60 & 1.80 & 0.00 \\
Low inorganic & 1.37 & 2.17 & 19.80 & 2.81 & 9.90 & 8.25 & 5.20 & 2.70 & 0.00 \\
High inorganic & 1.30 & 1.90 & 20.43 & 2.25 & 14.20 & 8.30 & 5.90 & 2.70 & 0.00 \\
Low organic & 1.50 & 1.72 & 17.50 & 2.95 & 8.25 & 6.65 & 5.00 & 2.75 & 0.00 \\
High organic & 1.42 & 1.80 & 18.20 & 2.85 & 11.45 & 6.90 & 5.06 & 1.65 & 0.00 \\
\hline
\end{tabular}

The strawberry soil samples for the control, all treatments, were examined for weight percentages of significant elements. It should be noted that the strawberry plants were obtained from a local Esmalia and that laboratory. First, we compared elements observed in the control and treatment strawberry soil samples. All elements that had higher weight percentages in treatment soil samples when compared with control, were phosphorus, calcium, and chlorine. The next comparison involved examining the amount of sulfur in the control soil sample and comparing it to the amount in the treatment soil samples. It was observed that the amount of sulfur in the treatment samples was lower than the amount of sulfur in the control plants indicating that sulfur was being absorbed. Also, the amount of sulfur in the high treatment soil samples was higher than the amount of sulfur in the low treatment soil samples, which again suggests that $\mathrm{Se}$ in substituting for sulfur in the plants that absorbed more Se, and more sulfur is left in the soil of the plants that did not absorb as much Se.

In general, the trend in variation of Se concentration in plants indicates higher Se levels in plants from aridic zones than in those from humidic zones. It may be summed that $\mathrm{Se}$ in plants is positively correlated with $\mathrm{pH}$, salinity, and $\mathrm{CaCo}_{3}$ in soils. High levels of Se in plants may also occur near seacoasts where the return of Se to land surfaces may be higher than in other regions because of sea spray. Increasing Se 
levels in plants suppresses concentrations of $\mathrm{N}, \mathrm{P}$, and $S$ as well as of several amino acids. Also, the absorption of heavy metals, mainly $\mathrm{Mn}, \mathrm{Zn}, \mathrm{Cu}, \mathrm{Fe}$ and $\mathrm{Cd}$ is inhibited by increasing Se. This relationship is dependent on the ratio between the elements, and thus some stimulating effects of high Se concentrations on uptake of heavy metals may also be expected. The application of $\mathrm{P}, \mathrm{S}$ and $\mathrm{N}$ is known to help in detoxifying Se, which may be a result either of depressing the Se uptake by roots or of establishing a beneficial ratio of $\mathrm{Se}$ to these elements, even when the Se content of plants is elevated. There is also a report that addition of lime, $\mathrm{S}, \mathrm{B}$, and Mo to the soil under field conditions did not affect the Se concentration is plant tissues (Gupta et al., 1975).

\section{REFERENCES}

Anderson, J. W.; Scar, A.R.(1983):Selenium and plant metabolism in Metals and Micronutriets: uptake and utilization by plants : Robb. D.A., Pierpoint, W. S. Ed.; Academic press: New York.

Bisberg, B.; Gissel-Nielsen, G.(1969):The uptake of Applied selenium by agricultural plants .1- the influence of soil type and plant species. Plant soil .31:287 -298

Burk. R.F.; Hill, K. E.(1993): Regulation of selenoproteins. In Annual Review of Nutrition, $13^{\text {th }}$ ed.; Olson, R., Bier, D., Mecormick, D., Eds.; Annuais Reviews, Inc.; Palo Alto.CA.pp:65-81 .

Carlson, C. L.; Kaplan, D. L.; Arao, D.C.(1989):Effects of selenium on germination and radicle elongation of selected agronomic species. Environ.Exp.Bot.,29,493-98.

Carvalho, K.M.; Benson, R.F.; Booth, F.A.; Collier, M.J.; Martin, D.F.(2000):Analysis of commercial seleniumsupplement tables. Florida Scient.63:8-12

Cary, E.E.; Allaway, W H. (1973) :Selenium content of field crops grown on selenite-treated soils. Agron.J.65:922-925

Clark, L. C.; Combs, G.F.; Jr.; Turnbull, B.W.; Slate, E.H.; Chalker, D.K.;Cho, J.;

Davis , L .S .; Glover, R.A.; Graham, G.F. Grosss, E.G.; Krongrad,A.;Lesher ,

J.L.; Park, H.K.; Sanders, B.B.; Jr.; Smith,C.L.; Taylor, J.R.(1996):Effects of selenium supplementation for cancer prevention in patients with carcinoma of the skin a randomized controlled trial. JAMA.. Am. Med. Assoc. 276:1957-1963 .

El-Ghanam, M. M. M. and El-Ghozoli ,M . A.(2006) :Behaviour of selenium in a calcareous soil treated with humic acid.Annals of Agri.Sc.,Moshtohor.44(1):407-24.

El-Raies, S . A . A . (2001) : Selenium presence and behaviour in soil and plant.1-Sein Giza governorate , Egypt .J.Agric.Sci. Mansoura Univ.,26:5855-5861 .

El-Raies, S.A.A.; El-Ghanam, M.M.M and M.A. ElAbaseri(2004): A preliminary point out on selenium status in some crop residues. Annals of Agric. Sc. Moshtohor. 42(1):393-400
Eurola, M .; Ekholm , P .; Ylinen ,M .; Koivistoinen ,P.;Varo,P.(1989):Effects of selenium fertilization on the selenium content of selected finnish fruits and vegetables .Acta Agric.Scand.39:345-350 .

Frankenberger, W .T.; Jr ; Engberg ,R . A .(1998) : Environmental chemistry of selenium ;Marcel Dekker. New York.

Ghanam, M.M.M.;S.A .A.El-Raies and M. A. El-Abaseri. (2003): Selenium status in the soil and berseem plants in South Tahreer. Egypt. J. Appl. Sci.18(12):389-400.

Gissal - Nielsen ,F.;Bisberg,B.(1970):The uptake of applied selenium by agricultural plants.2-The utilization of various selenium compounds. Plant soil.32:382-396.

Gissel - Nielsen, G.(1977):Control of selenium in plants. Risoe Rep.No.370,13app .

Gissal - Nielson, G. (1998): Effects of selenium supplementation of field crops. In Environmental Chemistry of selenium frankenberger, W.T.,Jr. Engberg, R.A., Eds.;

Gomez, K.A. and Gomez ,A.A.(1984): Statistical procedures for agricultural Research . $2^{\text {nd }}$ ed ., Wiley, New York .Marcel Dekker:New York.,pp.99-112 .

Gupta, U. C.and Winter ,K .A. (1975): Selenium content of soils and crops and the effects of lime and sulfur on plant selenium, Con.J.Soil Sci.55.161.

Inhat ,M . (1992) :Selenium .In hazardous metals in the environment techniques and instrumentation in analytical chemistry; Stoeppler, M., Ed.; Elsevier: Amsterdam. $\mathrm{pp}, 457-515$.

Jackson, M. L.(1973) :Soil chemical analysis. Printice Hall. Inc., Englewood Clifs, N.J.Library of congress, USA.

Mayland, H.F.;L .F.; Jame; K.E. Panter and J.L. Sondergger (1989): Selenium is seleniferous environments. Soil Science Society of merican and American society of Agronoimy ;677:15 .

National Research Council. Selenium in nutrition, revised edition; National Academy press:Washington,DC,1983.

National Research Council.Recommended dietary allowances, $10^{\text {th }}$ ed .; National Academy press :Washington, DC,1989 .

Page,A.L .;Miller ,R .H. and Keeney, D. R. (1982) :Methods of soil analysis .Part2 : Chemical and microbiological properties. Second Edition .Agron.J.9:2 .

Piper, C.S. (1950): Soil and plant analysis. $1^{\text {st }}$ Ed.Inter.Publishers, New York, USA, pp.47-79.

Rayman, M. P.(2002):The argument for increasing selenium intake .Proc.Nutr.Soc.61(2),203-215

Rayman, M.P.(2002):Se brought to earth. Chem. Br,39(10)2831 .

Wyatt,C.J.;Melendez,J .M.; Acuna, N.; Rascon, A. (1996) : Selenium in foods in Northern Mexico, their contribution to the daily $\mathrm{Se}$ intake and the relationship of Se plasma levels and glutathione peroxidase activity. Nutr.Res.16:949-960.

Ylaranta, T. (1985): Increasing the selenium content of cereal and grass crops in Finland. Dissertation, University of Helsinki, Finland. 